\title{
Does yeast (Saccharomyces cerevisiae) supplementation in calf starter modify feed intake and liveweight gain of dairy bull calves?
}

\author{
A. Huuskonen ${ }^{1}$ and M. Pesonen \\ Natural Resources Institute Finland (Luke), Green Technology \\ Tutkimusasemantie 15, Fl-92400 Ruukki, Finland
}

KEY WORDS: calves, nutrition, live yeast, growth performance, health

Received: $\quad 9$ April 2015

Revised: $\quad 28$ October 2015

Accepted: 25 November 2015

${ }^{1}$ Corresponding author:

e-mail: arto.huuskonen@luke.fi

\begin{abstract}
The objective of the experiment was to study the possible effects of supplemental yeast culture in calf starter on feed intake, liveweight gain and health of dairy bull calves. Two feeding treatments consisted of a calf starter containing $0 \%$ and $0.1 \%$ supplemental yeast culture (Actisaf, $1.0 \times 10^{10} \mathrm{CFU} \cdot \mathrm{g}^{-1}$ Saccharomyces cerevisiae Sc 47) as a percentage of dry matter starter. In each feeding treatment 20 dairy bull calves were included. The calves were housed in insulated barn in four pens ( $3.0 \times 3.5 \mathrm{~m} ; 5$ calves in each), providing $2.1 \mathrm{~m}^{2}$ per calf. At the beginning of the experiment, the average liveweight of the calves was $56 \pm 3.0 \mathrm{~kg}$ and the overall age was $20 \pm 2.5$ days. During the pre-weaning period (from 20 to 75 day of life) the calves received milk replacer $7.0 \mathrm{I} \cdot \mathrm{d}^{-1}$ and starter concentrate as well as grass silage ad libitum. During the post-weaning period (from 75 to 195 day of life) the calves received grass silage ad libitum, but the amount of concentrate was restricted to $3 \mathrm{~kg}$ (air dry) for a calf per day. No treatment differences were observed in dry matter or energy intakes, liveweight gain or feed conversion ratio during pre-weaning or post-weaning periods. The use of Saccharomyces cerevisiae did not affect the incidence of diarrhoea, cough or bloat. Thus, no evidence show that Saccharomyces cerevisiae inclusion could have enhanced calf performance under the studied conditions. In the present experiment, the calves were healthy; however different results might be observed in calves in altered physiological conditions.
\end{abstract}

\section{Introduction}

Good growth performance of calves is an important aspect of dairy herd management. Replacement heifers need an appropriate start to become productive dairy cows, and successful rearing of bull calves allows to fully exploit their growth potential in beef production. The process of transitioning dairy calves from their neonatal reliance on nutrients supplied from milk or milk replacer to nutrients supplied from solid feed is of substantial economic importance for the producer (Khan et al., 2008).
In many intensive dairy and beef systems, dairy calves are typically fed commercial calf starters and grass silage as solid feed during the first months.

Incorporation of microbial additives such as a culture of Saccharomyces cerevisiae to the diet has become a common practice in ruminant nutrition (Chaucheyras-Durand et al., 2008; Magalhães et al., 2008; Desnoyers et al., 2009, Kim et al., 2011). Influences of yeast culture supplementation on numerous growth and production traits have been studied in most ruminant age classes (Chaucheyras-Durand et al., 2008; Magalhães et al., 2008; Marden et al., 
2008; Pinos-Rodríguez et al., 2008; Desnoyers et al., 2009; Lascano and Heinrichs, 2009). In vitro and in vivo studies have shown that yeasts and yeast cultures stimulate growth of rumen cellulolytic bacteria (Callaway and Martin, 1997), which are critical for carbohydrate digestion and rumen development in newborn calves. This progress in rumen microbial activities might partially explain the improvements observed in calf growth when yeast or yeast culture were incorporated into the diet in some studies (Lesmeister et al., 2004; Galvão et al., 2005). It is also suggested that yeast culture improves health of the young calves' digestive tract and reduces morbidity and mortality. Diarrhoea in calves can be caused by pathogenic bacteria that attach and may or may not invade the intestinal cells of the host (Magalhães et al., 2008). It is possible that feeding animals with diet enriched with yeast culture may decrease the risk of diarrhoea by reducing the attachment and invasion of intestinal cells by pathogens, because they may bind to oligosaccharides present in the yeast cell wall (White et al., 2002; Pérez-Sotelo et al., 2005), minimizing the growth of enteric pathogens (Jensen et al., 2008) or reducing inflammatory response in the gut because of the metabolites of yeast culture (Jensen et al., 2007).

However, results are inconsistent in the literature, partially because of confounding effects of ration composition, level of yeast culture inclusion and source of yeast culture product tested. In addition, only a few studies have utilized pre-ruminant dairy calves. Therefore, the present experiment was designed to study the effects of supplemental yeast (Saccharomyces cerevisiae) culture in calf starter on feed intake, liveweight gain, feed conversion ratio and health of dairy bull calves. It was hypothesized that Saccharomyces cerevisiae addition in a dairy calf starter would increase feed intake and improve calves' liveweight gain and feed efficiency.

\section{Material and methods}

\section{Animals, management and experimental design}

The present experiment included two batches of 20 Nordic Red dairy bull calves each. The first batch of the calves started in April and the second in November 2013 in the experimental barn of Natural Resources Institute in Finland (Luke; former MTT Agrifood Research Finland) in Ruukki (Finland; $64^{\circ} 44^{\prime} \mathrm{N}, 25^{\circ} 15^{\prime} \mathrm{E}$ ). Animals were managed in accordance to the Finnish legislation regarding the use of animals in scientific experiments. All calves were purchased from local dairy farms.
The calves were housed in an insulated barn in four pens $(3.0 \times 3.5 \mathrm{~m} ; 5$ calves in each), providing $2.1 \mathrm{~m}^{2}$ per calf. The floor of the pen was built in $1 / 3$ of metal slats and in $2 / 3$ of rubber mats. The ambient temperature of the insulated barn varied between 11 and $20^{\circ} \mathrm{C}$ in the winter (October-April) and between 15 and $23{ }^{\circ} \mathrm{C}$ in the summer (MaySeptember). At the beginning of the experiment the calves in both batches were randomly placed in pens ( 5 calves per pen) and then randomly allotted to two feeding treatments.

The two feeding treatments consisted of a calf starter containing $0 \%($ control $=\mathrm{C})$ and $0.1 \%$ (yeast $=\mathrm{Y}$ ) supplemental live yeast culture (Actisaf, $1.0 \times 10^{10} \mathrm{CFU} \cdot \mathrm{g}^{-1}$ Saccharomyces cerevisiae $\mathrm{Sc} 47$ ) as a percentage of the dry matter (DM) starter. Both feeding treatments included 20 bull calves (4 pens, 5 calves in each). At the beginning of the experiment, the average liveweight (LW) of the calves was $56 \pm 3.0 \mathrm{~kg}$ (mean $\pm \mathrm{SD}$ ) and the overall age $20 \pm 2.5$ days. During the whole 175-day experimental period (from 20 to 195 day of life) the calves were given free access to water from an open water bowl (1 bowl per pen). The bowls were $80 \mathrm{~mm}$ deep, $220 \mathrm{~mm}$ in diameter and of two litres capacity.

\section{Feeds and feeding}

During the pre-weaning period (from 20 to 75 day of life) the calves received a milk replacer (MR) at a dilution of $11.9 \%$ DM. The MR included $\left(\mathrm{g} \cdot \mathrm{kg}^{-1} \mathrm{DM}\right)$ skim milk powder 300 , whey powder 283 , vegetable oil 190, whey fractions 100 , hydrolysed wheat protein 65 , wheat starch 50 and vitaminmineral premix 12. In both treatments the MR was served by a computer-controlled feeder (two pens per feeder; Stand Alone 2 Plus, Förster, Engen, Germany; programme: Kalbmanager 4.2) in the feeding temperature of $37^{\circ} \mathrm{C}$. The calves were assigned to the feeding treatments on 20 day of life, and between 20 and 62 day the highest possible MR allowance of the calves was $7.01 \cdot \mathrm{d}^{-1}$. All calves were weaned gradually from day 62 to 75 with reduction of MR allowance (less MR portions per day). During the pre-weaning period, the calves had free access to commercial pelleted calf starter and grass silage.

During the post-weaning period (from 75 to 195 day of life) the calves were fed grass silage ad libitum, but the amount of concentrate was restricted to $3 \mathrm{~kg}$ (air dry) for a calf per day. The commercial starter concentrate used during both pre- and post-weaning periods was supplied by A-Rehu Ltd. (Seinäjoki, Finland). The concentrate in the treatment $\mathrm{C}$ comprised $\left(\mathrm{g} \cdot \mathrm{kg}^{-1} \mathrm{DM}\right)$ barley 333 , rapeseed meal 174 , wheat 80 , barley fibre 72 , molassed sugar beet pulp 70 , soyabean meal 50 , 
oats 50 , molasses 50 , rapeseed cake 42 , distilled solubles $40, \mathrm{CaCo}_{3} 20$, vegetable oil mix 8 , and vitamin, mineral and trace element premix 11 . In the treatment $Y$ the concentrate was otherwise the same, but comprised barley (332) and supplemental yeast culture (1) (Saccharomyces cerevisiae Sc 47). The used dose of yeast culture was established according to Lascano and Heinrichs (2009). Kim et al. (2011) stated that yeast has been typically included in calf diets at levels between $0.001 \%$ and $1 \%$, with some positive effects on DM intake, rumen $\mathrm{pH}$ and nutrient digestibility.

The silage and concentrates were offered separately from feeder box three times a day (at 8:00, $12: 00$ and 18:00) with proportional refusals at $5 \%$ in ad libitum feeding. The unconsumed feed was collected and measured daily at 7:00. Daily solid feed intake was weighed pen wise (i.e. average for five calves).

The grass silage used in the present experiment was harvested from first-year stands grown in Ruukki (Finland). The silage was prepared from primary growth of Phleum pratense stand and harvested at early stages of maturity. The silage was cut using a mower conditioner, wilted for $5 \mathrm{~h}$, harvested using a precision-chop forage harvester, ensiled in a bunker silo and treated with a formic acid-based additive (AIV ÄSSÄ; Taminco Finland Ltd., Oulu, Finland; $\mathrm{g} \cdot \mathrm{kg}^{-1}$ : formic acid 590, propionic acid 200, ammonium formate 40 and benzoic acid 25) applied at a rate of 51 per tonne of fresh forage.

\section{Feed sampling and chemical analysis}

During the experiment, silage sub-samples were taken twice a week, pooled over periods of four weeks and stored at $-20{ }^{\circ} \mathrm{C}$ prior to analyses. Thawed samples were analysed for DM, ash, crude protein $(\mathrm{CP})$, crude fat, starch, fermentation quality $(\mathrm{pH}$, water-soluble carbohydrates, lactic and formic acids, volatile fatty acids, soluble and ammonia $\mathrm{N}$ content of total $\mathrm{N}$ ) and digestible organic matter in DM (D-value). Concentrate and MR subsamples were collected weekly, pooled over periods of 12 weeks and analysed for DM, ash, CP, crude fat and starch.

Fresh silage samples were analysed for fermentation quality by electrometric titration as described by Moisio and Heikonen (1989). The DM concentration was determined by drying at $105{ }^{\circ} \mathrm{C}$ for $20 \mathrm{~h}$ and organic matter (OM) concentration by ashing at $600{ }^{\circ} \mathrm{C}$ for $2 \mathrm{~h}$. Oven DM concentration of silages was corrected for the loss of volatiles according to Huida et al. (1986). After drying, samples were milled by using sample mill (Sakomylly KT-3100, Koneteollisuus Oy, Helsinki, Finland) into $1 \mathrm{~mm}$ sieve. The $\mathrm{CP}$ content of feeds was determined by using a Dumas-type N analyser (Leco FP428; Leco Corporation, St. Joseph, MI, USA), crude fat - according to Pesonen et al. (2013) and starch as described by Huuskonen et al. (2014). The silage samples were analysed for D-value as described by Huuskonen (2013).

\section{Calculations}

Concentration of metabolizable energy (ME) of the silage was calculated from the concentration of digestible organic matter (DOM) using equation (MAFF, 1984):

$$
\begin{gathered}
\mathrm{ME}\left(\mathrm{MJ} \cdot \mathrm{kg}^{-1} \mathrm{DM}\right)=16.0\left(\mathrm{MJ} \cdot \mathrm{kg}^{-1} \mathrm{DM}\right) \times \mathrm{DOM} \\
\left(\mathrm{kg} \cdot \mathrm{kg}^{-1} \mathrm{DM}\right) .
\end{gathered}
$$

The ME values of concentrates and milk replacers were calculated as described by Schiemann et al. (1972).

The calves were weighed on two consecutive days at the beginning of the experiment and then after every 14 days during the pre-weaning period and every 28 days during the post-weaning period. The liveweight gain (LWG) was calculated as the difference between initial and final LW divided by the number of growing days. Intakes of MR, concentrates and silage were recorded daily. Overall, total DM intake (MR, concentrate and silage) and feed efficiency $\left(\mathrm{kg} \mathrm{DM} \cdot \mathrm{kg}^{-1} \mathrm{LWG}\right.$ and $\mathrm{MJ} \cdot \mathrm{kg}^{-1}$ LWG) were also calculated. Health parameters such as faecal consistency (normal or diarrhoea), bloat, movements, cough, inflammations, e.g., pneumonia, swollen joints and hair loss, were monitored daily. Incidences are reported as a percentage of feeding days during the pre-weaning period.

\section{Statistical analysis}

The results were calculated across the two batches and are shown as least squares means. The pen (a group of five calves) was used as an experimental unit and thus the mean values for each pen were calculated. There were 4 pens per treatment (20 calves for each treatment). The average group feed intake and growth data were subjected to analysis of variance using the SAS MIXED procedure (version 9.3, SAS Institute Inc. Cary, NC; Littell et al., 1996). The statistical model used:

$$
\mathrm{y}_{\mathrm{jkl}}=\mu+\beta_{\mathrm{k}}+\alpha_{\mathrm{j}}+(\beta \times \alpha)_{\mathrm{jk}}+\mathrm{e}_{\mathrm{jk} \mathrm{l}}
$$

where: $\mu$ - overall mean, $e_{j k l}$ - random error term, $\mathrm{y}_{\mathrm{jk} \mathrm{k}}$ - mean of five animals penned together (4 pens per treatment; $1=1, \ldots \ldots, 4) . \alpha, \beta$ and $\beta \times \alpha$-effects of treatment, batch and their interaction, respectively.

$P$-values less than 0.05 are reported as statistically significant. 


\section{Results}

Chemical composition and feeding values of the experimental feeds are presented in Table 1. The commercial starter concentrate contained ME $12.4 \mathrm{MJ} \cdot \mathrm{kg}^{-1} \mathrm{DM}$ and CP $198 \mathrm{~g} \cdot \mathrm{kg}^{-1} \mathrm{DM}$ on average. The grass silage used was of good nutritional quality as indicated by the ME value

Table 1. Chemical composition and feeding values of experimental feeds

\begin{tabular}{lclcl}
\hline Indices & $\begin{array}{l}\text { Grass } \\
\text { silage }\end{array}$ & $\begin{array}{l}\text { Milk } \\
\text { replacer }\end{array}$ & $\begin{array}{c}\text { Control } \\
\text { starter }\end{array}$ & Yeast \\
& starter \\
\hline Dry matter $(\mathrm{DM}), \mathrm{g} \cdot \mathrm{kg}^{-1}$ feed & 287 & 943 & 856 & 865 \\
Organic matter, $\mathrm{g} \cdot \mathrm{kg}^{-1} \mathrm{DM}$ & 932 & 910 & 920 & 922 \\
Crude protein, $\mathrm{g} \cdot \mathrm{kg}^{-1} \mathrm{DM}$ & 138 & 216 & 203 & 193 \\
Crude fat, $\mathrm{g} \cdot \mathrm{kg}{ }^{-1} \mathrm{DM}$ & 39 & 114 & 38 & 40 \\
Starch, $\mathrm{g} \cdot \mathrm{kg}^{-1} \mathrm{DM}$ & 5 & 100 & 313 & 295 \\
Metabolizable energy, MJ $\cdot \mathrm{kg}^{-1} \mathrm{DM}$ & 10.6 & 17.4 & 12.4 & 12.4 \\
\hline
\end{tabular}

control starter - a calf starter containing $0 \%$ supplemental yeast culture, yeast starter - a calf starter containing $0.1 \%$ supplemental yeast culture (Actisaf, Saccharomyces cerevisiae Sc 47) of starter DM. Fermentation quality of grass silage: $\mathrm{pH} 3.96$; volatile fatty acids $11 \mathrm{~g} \cdot \mathrm{kg}^{-1} \mathrm{DM}$; lactic + formic acid $41 \mathrm{~g} \cdot \mathrm{kg}^{-1} \mathrm{DM}$; water-soluble carbohydrates $56 \mathrm{~g} \cdot \mathrm{kg}^{-1} \mathrm{DM}$; ammonia-N $39 \mathrm{~g} \cdot \mathrm{kg}^{-1}$ total $\mathrm{N}$; soluble $\mathrm{N}$ $423 \mathrm{~g} \cdot \mathrm{kg}^{-1}$ total $\mathrm{N}$

Table 2. Daily feed and nutrient intakes of dairy calves fed diets consisting calf starter containing $0 \%$ (control) or $0.1 \%$ (yeast) supplemental live yeast culture (Actisaf, Saccharomyces cerevisiae Sc 47) as a percentage of starter dry matter (DM)

\begin{tabular}{|c|c|c|c|c|}
\hline \multirow{2}{*}{ Indices } & \multicolumn{2}{|l|}{ Diets } & \multirow{2}{*}{ SEM } & \multirow{2}{*}{$P$} \\
\hline & control & yeast & & \\
\hline Number of calves & 20 & 20 & & \\
\hline Number of pens & 4 & 4 & & \\
\hline \multicolumn{5}{|c|}{ Pre-weaning (between 20 to 75 days of age) } \\
\hline milk replacer, $\mathrm{kg} \mathrm{DM} \cdot \mathrm{d}^{-1}$ & 0.71 & 0.72 & 0.010 & 0.41 \\
\hline concentrate, $\mathrm{kg} \mathrm{DM} \cdot \mathrm{d}^{-1}$ & 0.69 & 0.67 & 0.065 & 0.76 \\
\hline grass silage, $\mathrm{kg} \mathrm{DM} \cdot \mathrm{d}^{-1}$ & 0.30 & 0.25 & 0.019 & 0.17 \\
\hline total DM intake, $\mathrm{kg} \mathrm{DM} \cdot \mathrm{d}^{-1}$ & 1.70 & 1.64 & 0.087 & 0.64 \\
\hline metabolizable energy, $\mathrm{MJ} \cdot \mathrm{d}^{-1}$ & 24.1 & 23.5 & 1.08 & 0.71 \\
\hline crude protein, $g \cdot d^{-1}$ & 334 & 318 & 16.5 & 0.52 \\
\hline crude fat, $\mathrm{g} \cdot \mathrm{d}^{-1}$ & 121 & 120 & 3.8 & 0.99 \\
\hline \multicolumn{5}{|c|}{ Post-weaning (between 75 to 195 days of age) } \\
\hline concentrate, $\mathrm{kg} \mathrm{DM} \cdot \mathrm{d}^{-1}$ & 2.48 & 2.46 & 0.030 & 0.71 \\
\hline grass silage, $\mathrm{kg} \mathrm{DM} \cdot \mathrm{d}^{-1}$ & 2.80 & 2.73 & 0.103 & 0.66 \\
\hline total DM intake, $\mathrm{kg} \mathrm{DM} \cdot \mathrm{d}^{-1}$ & 5.27 & 5.19 & 0.125 & 0.65 \\
\hline metabolizable energy, $\mathrm{MJ} \cdot \mathrm{d}^{-1}$ & 60.4 & 59.4 & 1.36 & 0.65 \\
\hline crude protein, $\mathrm{g} \cdot \mathrm{d}^{-1}$ & 890 & 852 & 18.7 & 0.23 \\
\hline crude fat, $g \cdot d^{-1}$ & 204 & 206 & 4.8 & 0.83 \\
\hline \multicolumn{5}{|l|}{ Average during the experiment } \\
\hline milk replacer, $\mathrm{kg} \mathrm{DM} \cdot \mathrm{g} \cdot \mathrm{d}^{-1}$ & 0.24 & 0.24 & 0.003 & 0.41 \\
\hline concentrate, $\mathrm{kg} \mathrm{DM} \cdot \mathrm{g} \cdot \mathrm{d}^{-1}$ & 1.88 & 1.86 & 0.041 & 0.73 \\
\hline grass silage, $\mathrm{kg} \mathrm{DM} \cdot \mathrm{g} \cdot \mathrm{d}^{-1}$ & 1.97 & 1.91 & 0.074 & 0.60 \\
\hline total DM intake, $\mathrm{kg} \mathrm{DM} \cdot \mathrm{g} \cdot \mathrm{d}^{-1}$ & 4.09 & 4.01 & 0.107 & 0.64 \\
\hline metabolizable energy, $\mathrm{MJ} \cdot \mathrm{g} \cdot \mathrm{d}^{-1}$ & 48.3 & 47.5 & 1.20 & 0.65 \\
\hline crude protein, $g \cdot d^{-1}$ & 705 & 674 & 17.0 & 0.27 \\
\hline crude fat, $g \cdot d^{-1}$ & 177 & 178 & 0.004 & 0.87 \\
\hline
\end{tabular}

SEM - standard error of means as well as the $\mathrm{CP}$ content. The fermentation quality of the grass silage was good, as indicated by low $\mathrm{pH}$ value (3.96) and low contents of ammonia $\mathrm{N}\left(39 \mathrm{~g} \cdot \mathrm{kg}^{-1}\right.$ total $\left.\mathrm{N}\right)$ and volatile fatty acids $\left(11 \mathrm{~g} \cdot \mathrm{kg}^{-1} \mathrm{DM}\right)$. The silage used was restrictively fermented with high residual water-soluble carbohydrates concentration $\left(56 \mathrm{~g} \cdot \mathrm{kg}^{-1} \mathrm{DM}\right)$ and low lactic acid concentration (lactic + formic acid, $\left.41 \mathrm{~g} \cdot \mathrm{kg}^{-1} \mathrm{DM}\right)$. The MR used in the present experiment had typical chemical composition and feed values (Table 1).

There were no treatment differences in the MR, concentrate, grass silage and total DM intake of the calves during pre-weaning or post-weaning periods as well as on average during the whole experiment (Table 2). Since there were observed no differences in the feed intake or diet chemical compositions and feeding values, the energy and nutrient intakes were also at the same level in both treatments.

The average LW of the calves was 101 and $247 \mathrm{~kg}$ at the end of pre-weaning period and at 195-day of life, respectively (Table 3). There were no treatment differences in the average LW and LWG of the calves. The use of Saccharomyces cerevisiae

Table 3. Liveweights, liveweight gains, feed conversion rates and disorders of dairy calves fed diets consisting calf starter containing $0 \%$ (control) or $0.1 \%$ (yeast) supplemental live yeast culture (Actisaf, Saccharomyces cerevisiae Sc 47) as a percentage of starter dry matter (DM)

\begin{tabular}{|c|c|c|c|c|}
\hline \multirow{2}{*}{ Indices } & \multicolumn{2}{|l|}{ Diets } & \multirow{2}{*}{ SEM } & \multirow{2}{*}{$P$} \\
\hline & control & yeast & & \\
\hline Number of calves & 20 & 20 & & \\
\hline Number of pens & 4 & 4 & & \\
\hline \multicolumn{5}{|l|}{ Liveweight, kg } \\
\hline initial, at age of 20 days & 57 & 55 & 3.3 & 0.71 \\
\hline at the end of pre-weaning & 103 & 98 & 5.4 & 0.51 \\
\hline final, at age of 195 days & 249 & 244 & 8.5 & 0.71 \\
\hline \multicolumn{5}{|l|}{ Liveweight gain, $g \cdot d^{-1}$} \\
\hline $\begin{array}{l}\text { pre-weaning (between } \\
20 \text { to } 75 \text { days of age) }\end{array}$ & 824 & 760 & 52.2 & 0.43 \\
\hline $\begin{array}{l}\text { post-weaning (between } \\
75 \text { to } 195 \text { days of age) }\end{array}$ & 1298 & 1304 & 35.6 & 0.92 \\
\hline average & 1141 & 1123 & 37.1 & 0.75 \\
\hline
\end{tabular}

Feed conversion ratio, $\mathrm{kg} \mathrm{DM} \cdot \mathrm{kg}^{-1}$ liveweight gain

$\begin{array}{lllll}\text { pre-weaning } & 2.17 & 2.21 & 0.039 & 0.51 \\ \text { post-weaning } & 4.08 & 4.02 & 0.121 & 0.75 \\ \text { average } & 3.60 & 3.60 & 0.091 & 0.99\end{array}$

Energy convertion ratio, $\mathrm{MJ} \cdot \mathrm{kg}^{-1}$

liveweight gain

$\begin{array}{lllll}\text { pre-weaning } & 30.7 & 31.6 & 0.78 & 0.49 \\ \text { post-weaning } & 46.7 & 46.0 & 1.34 & 0.75 \\ \text { average } & 42.6 & 42.6 & 1.04 & 0.98\end{array}$

Disorders during pre-weaning period, $\%$ of feeding days

\begin{tabular}{lllll} 
diarrhoea & 1.65 & 2.10 & 0.512 & 0.86 \\
cough & 1.54 & 1.41 & 0.380 & 0.67 \\
bloat & 0.19 & 0.11 & 0.118 & 0.33 \\
\hline
\end{tabular}

SEM - standard error of means 
did not affect the feed or energy conversion rates of the calves. Furthermore, the use of Saccharomyces cerevisiae had no influence on the incidence of diarrhoea, cough or bloat (days, $\%$ of feeding days during the pre-weaning period).

\section{Discussion}

In comparison to the recent Finnish experimental data sets for dairy bull calves fed diets based on MR, grass silage and concentrates in similar housing environments (Huuskonen et al., 2005, 2011a,b; Huuskonen and Khalili, 2008; Huuskonen, 2011), the average DM intake of calves during the pre-weaning and post-weaning periods was approximately $20 \%$ higher in the present experiment (1.67 and $5.23 \mathrm{~kg} \mathrm{DM} \cdot \mathrm{d}^{-1}$, for pre- and post-weaning period, respectively) than in the above-mentioned feeding trials (1.36 and $\left.4.27 \mathrm{~kg} \mathrm{DM} \cdot \mathrm{d}^{-1}\right)$. The high feed intake measured in the present study probably implies a good palatability of the starter concentrate used and a good health of the calves in the present experiment. The average LWG of the calves during the pre- and post-weaning period and during the entire experiment were 792,1301 and $1132 \mathrm{~g} \cdot \mathrm{d}^{-1}$, respectively. This data is slightly higher when compared with the results by Huuskonen and Khalili (2008) and Huuskonen et al. (2005, 2011a,b) about dairy bull calves fed diets based on MR, grass silage and concentrates under similar management conditions (724, 1258 and $1080 \mathrm{~g} \cdot \mathrm{d}^{-1}$, respectively).

Contrary to the present study, supplemental yeast products have been shown to improve performance of dairy ruminants in some earlier studies, and the yeast impact was evident regarding the increased feed intake and milk production (Abd El-Ghani, 2004; Jouany, 2006; Stella et al., 2007). It have been reported that growth, feed intake and feed conversion ratio were improved by yeasts supplementation also in beef cattle and young ruminant animals (Lesmeister et al., 2004; Galvão et al., 2005). In neonatal dairy calves, Lesmeister et al. (2004) reported that inclusion of yeast culture (Saccharomyces cerevisiae) increased the starter and total DM intake and average daily gain when compared with the control treatment. However, results in dairy calves are inconsistent throughout the literature. Kim et al. (2011) reported no difference in feed intake, liveweight or feed efficiency when neonatal calves received either control calf starter or starter supplemented with $0.2 \%$ of hydrolysed yeast. Moreover, Quigley et al. (1992) observed a significant decrease in DM intake with supplemental yeast culture. It was also found out that DM intake has decreased when brewer's yeast (Seymour et al., 1995) or live yeast (Wagner et al., 1990) was added to calves diets. Similarly to the present study, Magalhães et al. (2008) observed that incorporation of yeast culture (Saccharomyces cerevisiae) at 2\% to the grain diet fed to the dairy calves between 2 to 70 days of life did not alter DM, protein and ME intake, feed efficiency and LWG.

In contrary to the present experiment, Magalhães et al. (2008) reported that calves fed yeast culture had decreased frequency of medical treatments because of reduced incidence of fever and diarrhoea and reduced overall morbidity. Also Kim et al. (2011) observed that calves from the hydrolysed yeast group showed better faecal and health scores after 3 weeks when compared with those in the control group. According to Chaucheyras-Durand et al. (2008), yeast responses vary depending on the strain of yeast used, the nature of the diet and the physiological status of the animal. Chaucheyras-Durand et al. (2008) concluded that the usage of supplemental yeast culture appears particularly relevant when the digestive microbiota is challenged, e.g., during a feed transition such as weaning, grazing, supply of high-concentrate diets, or during stressful periods, such as hot temperature or transportation. In dairy calves, Magalhães et al. (2008) concluded that under the conditions in which incidences of diarrhoea are high, yeast culture improves health of the digestive tract of young calves and reduces morbidity and mortality.

\section{Conclusions}

In conclusion, no treatment differences were observed in dry matter or energy intakes, liveweight gain, feed conversion ratio or health parameters of the calves in the present experiment. Based on earlier studies, it was hypothesized that Saccharomyces cerevisiae inclusion in a dairy calf starter would increase feed intake and improve growth and feed efficiency of dairy calves. However, the lack of differences in intake parameters and growth performance did not support this hypothesis. Thus, no evidence exists that Saccharomyces cerevisiae inclusion could have enhanced calf performance under the conditions of the present study. The calves in the present experiment were healthy; however different results might be observed in calves in altered physiological conditions. 


\section{Acknowledgements}

This study was partially funded by the Centre for Economic Development, Transport and the Environment for North Savo. We wish to express our gratitude also to Mr. Matti Huumonen and his personnel for technical assistance and their excellent care of the experimental animals. The evaluation of the manuscript by Professor Marketta Rinne is warmly acknowledged.

\section{References}

Abd El-Ghani A.A., 2004. Influence of diet supplementation with yeast culture (Saccharomyces cerevisiae) on performance of Zaraibi goats. Small Ruminant Res. 52, 223-229

Callaway E.S., Martin S.A., 1997. Effects of a Saccharomyces cerevisiae culture on ruminal bacteria that utilize lactate and digest cellulose. J. Dairy Sci. 80, 2035-2044

Chaucheyras-Durand F., Walker N.D., Bach A., 2008. Effects of active dry yeasts on the rumen microbial ecosystem: past, present and future. Anim. Feed Sci. Tech. 145, 5-26

Desnoyers M., Giger-Reverdin S., Bertin G., Duvaux-Ponter C., Sauvant D., 2009. Meta-analysis of the influence of Saccharomyces cerevisiae supplementation on ruminal parameters and milk production of ruminants. J. Dairy Sci. 92, 1620-1632

Galvão K.N., Santos J.E., Coscioni A., Villasenor M., Sischo W.M., Berge A.C., 2005. Effect of feeding live yeast products to calves with failure of passive transfer on performance and patterns of antibiotic resistance in fecal Escherichia coli. Reprod. Nutr. Develop. 45, 427-440

Huida L., Väätäinen H., Lampila M., 1986. Comparison of dry matter contents in grass silage as determined by oven drying and gas chromatographic water analysis. Ann. Agr. Fenn. 25, 215-230

Huuskonen A., 2011. Effects of barley grain processing method (steam-processed vs. dry-rolled) on intake and growth performance of dairy calves. Acta Agr. Scand. Sect. A - Anim. Sci. $61,137-144$

Huuskonen A., 2013. Performance of growing and finishing dairy bulls offered diets based on whole-crop barley silage with or without protein supplementation relative to a grass silage-based diet. Agr. Food Sci. 22, 424-434

Huuskonen A., Huumonen M., Joki-Tokola E., Tuomisto L., 2011a. Effects of different liquid feeding strategies during the pre-weaning period on the performance and carcass characteristics of dairy bull calves. Acta Agr. Scand. Sect. A - Anim. Sci. 61 187-195

Huuskonen A., Khalili H., 2008. Computer-controlled milk replacer feeding strategies for group-reared dairy calves. Livest. Sci. $113,302-306$

Huuskonen A., Khalili H., Kiljala J., Joki-Tokola E., Nousiainen J., 2005. Effects of vegetable fats versus lard in milk replacers on feed intake, digestibility, and growth in Finnish Ayrshire bull calves. J. Dairy Sci. 88, 3575-3581

Huuskonen A., Pesonen M., Joki-Tokola E., 2014. Effects of supplementary concentrate level and separate or total mixed ration feeding on performance of growing dairy bulls. Agr. Food Sci. 23, 257-265

Huuskonen A., Tuomisto L., Kauppinen R., 2011b. Effect of drinking water temperature on water intake and performance of dairy calves. J. Dairy Sci. 94, 2475-2480
Jensen G.S., Hart A.N., Schauss A.G., 2007. An antiinflammatory immunogen from yeast culture induces activation and alters chemokine receptor expression on human natural killer cells and B lymphocytes in vitro. Nutr. Res. 27, 327-335

Jensen G.S., Patterson K.M., Yoon I., 2008. Nutritional yeast culture has specific anti-microbial properties without affecting healthy flora. Preliminary results. J. Anim. Feed Sci. 17, 247-252

Jouany J.P., 2006. Optimizing rumen functions in the close-up transition period and early lactation to drive dry matter intake and energy balance in cows. Anim. Reprod. Sci. 96, 250-264

Khan M.A., Lee H.J., Lee W.S., Kim H.S., Kim S.B., Park S.B., Baek K.S., Ha J.K., Choi Y.J., 2008. Starch source evaluation in calf starter: II. Ruminal parameters, rumen development, nutrient digestibilities, and nitrogen utilization in Holstein calves. J. Dairy Sci. 91, 1140-1149

Kim M.H., Seo J.K., Yun C.H., Kang S.J., Ko J.Y., Ha J.K., 2011. Effects of hydrolyzed yeast supplementation in calf starter on immune responses to vaccine challenge in neonatal calves. Animal 5, 953-960

Lascano G.J., Heinrichs A.J., 2009. Rumen fermentation pattern of dairy heifers fed restricted amounts of low, medium, and high concentrate diets without and with yeast culture. Livest. Sci. $124,48-57$

Lesmeister K.E., Heinrichs A.J., Gabler M.T., 2004. Effects of supplemental yeast (Saccharomyces cerevisiae) culture on rumen development, growth characteristics, and blood parameters in neonatal dairy calves. J. Dairy Sci. 87, 1832-1839

Littell R.C., Milliken G.A., Stroup W.W., Wolfinger R.D., Schabenberger O., 1996. SAS for Mixed Models. $2^{\text {nd }}$ Edition. SAS Institute Inc. Cary, NC

Magalhães V.J.A., Susca F., Lima F.S., Branco A.F., Yoon I., Santos J.E.P., 2008. Effect of feeding yeast culture on performance, health, and immunocompetence of dairy calves. J. Dairy Sci. 91, 1497-1509

Marden J.P., Julien C., Monteils V., Auclair E., Moncoulon R., Bayourthe $C$., 2008. How does live yeast differ from sodium bicarbonate to stabilize ruminal $\mathrm{pH}$ in high-yielding dairy cows? J. Dairy Sci. 91, 3528-3535

MAFF, Ministry of Agriculture, Fisheries and Food, 1984. Energy Allowances and Feeding Systems for Ruminants. ADAS Reference Book 433. Ministry of Agriculture, Fisheries and Food. Her Majesty`s Stationery Office, London

Moisio T., Heikonen M., 1989. A titration method for silage assessment. Anim. Feed Sci. Tech. 22, 341-353

Pesonen M., Honkavaara M., Kämäräinen H., Tolonen T., Jaakkola M., Virtanen V., Huuskonen A., 2013. Effects of concentrate level and rapeseed meal supplementation on performance, carcass characteristics, meat quality and valuable cuts of Hereford and Charolais bulls offered grass silage-barley-based rations. Agr. Food Sci. 22, 151-167

Pérez-Sotelo L.S., Talavera-Rojas M., Monroy-Salazar H.G., LagunasBernabé S., Cuarón-Ibargüengoytia J.A., Jiménez R.M.O., Vázquez-Chagoyán J.C., 2005. In vitro evaluation of the binding capacity of Saccharomyces cerevisiae Sc47 to adhere to the wall of Salmonella spp. Rev. Latinoamer. Microbiol. 47, 70-75

Pinos-Rodríguez J.M., Robinson P.H., Ortega M.E., Berry S.L., Mendoza G., Bárcena R., 2008. Performance and rumen fermentation of dairy calves supplemented with Saccharomyces cervisiae $^{1077}$ or Saccharomyces boulardii ${ }^{1079}$. Anim. Feed Sci. Tech. 140, 223-232

Quigley J.D. 3rd, Wallis L.B., Dowlen H.H., Heitmann R.N., 1992. Sodium bicarbonate and yeast culture effects on ruminal fermentation, growth, and intake in dairy calves. J. Dairy Sci. $75,3531-3538$ 
Schiemann R., Nehring K., Hoffmann L., Jentsch W., Chudy A., 1972. Energetische Futterbewertung und Energienormen. VEB Deutscher Landwirtschaftsverlag. Berlin (Germany)

Seymour W.M., Nocek J.E., Siciliano-Jones J., 1995. Effects of a colostrum substitute and of dietary brewer's yeast on the health and performance of dairy calves. J. Dairy Sci. 78, 412-420

Stella A.V., Paratte R., Valnegri L., Cigalino G., Soncini G., Chevaux E., Dell'Orto V., Savoini G., 2007. Effect of administration of live Saccharomyces cerevisiae on milk production, milk composition, blood metabolites, and faecal flora in early lactating dairy goats. Small Ruminant Res. 67, 7-13
Wagner D.G., Quinonez J., Bush L.J., 1990. The effect of corn- or wheat-based diets and yeast culture on performance, ruminal $\mathrm{pH}$, and volatile fatty acids in dairy calves. Agri-Practice 11, 7-12

White L.A., Newman M.C., Cromwell G.L., Lindemann M.D., 2002. Brewers dried yeast as a source of mannan oligosaccharides for weanling pigs. J. Anim. Sci. 80, 2619-2628 